ACCEPTED MANUSCRIPT

\title{
On the contribution of fullerene to the current of planar heterojunction organic solar cells.
}

To cite this article before publication: Linda Cattin et al 2020 J. Phys. D: Appl. Phys. in press https://doi.org/10.1088/1361-6463/ab7c98

\section{Manuscript version: Accepted Manuscript}

Accepted Manuscript is "the version of the article accepted for publication including all changes made as a result of the peer review process, and which may also include the addition to the article by IOP Publishing of a header, an article ID, a cover sheet and/or an 'Accepted Manuscript' watermark, but excluding any other editing, typesetting or other changes made by IOP Publishing and/or its licensors"

This Accepted Manuscript is @ 2020 IOP Publishing Ltd.

During the embargo period (the 12 month period from the publication of the Version of Record of this article), the Accepted Manuscript is fully protected by copyright and cannot be reused or reposted elsewhere.

As the Version of Record of this article is going to be / has been published on a subscription basis, this Accepted Manuscript is available for reuse under a CC BY-NC-ND 3.0 licence after the 12 month embargo period.

After the embargo period, everyone is permitted to use copy and redistribute this article for non-commercial purposes only, provided that they adhere to all the terms of the licence https://creativecommons.org/licences/by-nc-nd/3.0

Although reasonable endeavours have been taken to obtain all necessary permissions from third parties to include their copyrighted content within this article, their full citation and copyright line may not be present in this Accepted Manuscript version. Before using any content from this article, please refer to the Version of Record on IOPscience once published for full citation and copyright details, as permissions will likely be required. All third party content is fully copyright protected, unless specifically stated otherwise in the figure caption in the Version of Record.

View the article online for updates and enhancements. 


\title{
On the contribution of fullerene to the current of planar heterojunction
} organic solar cells.

\author{
L. Cattin ${ }^{1}$, M. A. Cherif ${ }^{2,4}$, Z. El Jouad ${ }^{3}$, H. Ftouhi ${ }^{1,5}$, E.M. El-Menyawy ${ }^{6}$, A. El Mahlali ${ }^{1}$,

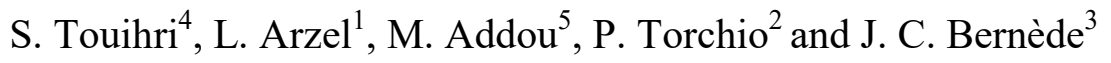

${ }^{1}$ Institut des Matériaux Jean Rouxel (IMN), CNRS-UMR 6502, Université de Nantes, 2 rue de la Houssinière, BP 32229, 44322 Nantes Cedex 3, France

${ }^{2}$ Aix-Marseille Université, Institut Matériaux Microélectronique Nanosciences de Provence IM2NP, CNRS-UMR 7334, Domaine Universitaire de Saint-Jérôme, 13397 Marseille Cedex 20, France

${ }^{3}$ MOLTECH-Anjou, CNRS-UMR 6200, Université de Nantes, 2 rue de la Houssinière, BP 92208, Nantes, F-44322, France

${ }^{4}$ UPDS, Faculté des Sciences de Tunis, Université de Tunis El Manar, Tunis, Tunisia

${ }^{5}$ Laboratoire des nanomatériaux et couches minces, FST, Université Abdelmalek Essaadi de Tétouan, FST de Tanger BP 416 - Tanger, Morocco

${ }^{6}$ Solid State Electronics Laboratory, Solid State Physics Department, Physics Research Division, National Research Centre, 33 El-Bohouth St., Dokki, Giza 12622, Egypt

\section{Summary}

Recently, significant progress in the field of organic photovoltaic cells was obtained by substituting new electron acceptor molecules to the fullerene, which was attributed to the fact that the fullerene absorption is quite small. Nevertheless, we demonstrate in the present work that, in the case of inverted cells, i.e. when the transparent bottom electrode is used as cathode, the contribution of fullerene to the Jsc short-circuit current of the cells, if not dominant, is not negligible; and that mainly in the short wavelength spectral range. The experimental results are confirmed by an optical simulation. Due to this significant contribution to Jsc, the light transmission of the transparent electrode towards the UV-part of the spectrum is crucial for inverse cell performances. When a transparent conductive electrode based on an alternative dielectric/metal/dielectric structure is substituted to ITO, such as $\mathrm{ZnS} / \mathrm{Ag} / \mathrm{TiO}_{2}$, the study allows to obtain promising results, although there is a loss of performance due to the decrease of transmission of $\mathrm{TiO}_{2}$ below $400 \mathrm{~nm}$ in wavelength.

Keywords: Organic solar cells, Planar heterojunction, External Quantum Efficiency, Absorption, Optical Modeling

Corresponding author: Jean Christian Bernède, jean-christian.bernede@univ-nantes.fr 


\section{Introduction}

Due to their lightweight, flexibility, semi-transparency [1] organic photovoltaic cells (OPVs) are complementary to silicon cells. The spectacular progress achieved in the field of OPVs is due to the use of low energy gap molecules [2], new electron acceptors [3], and optimization of their geometry [4, 5]. A basic OPV is made up of an organic active layer, consisting of an electron donor (ED) and an electron acceptor (EA), sandwiched between two electrodes, one of which being transparent. It is usual to employ this transparent layer, generally an ITO layer, as an anode. Such a configuration is called classic OPV (COPV). In contrast, when the transparent conductive electrode (TCE) is used as a cathode it is called inverted OPV (IOPV). It was shown that IOPVs are more stable than COPVs, hence the interest in studying these inverted structures, even if, at times, their performances are inferior to that of COPVs [6], but this is not sysyematically the case when the ED is SubPc [7].

Whatever their geometry, IOPV or COPV, two configurations are possible for the organic layer, either bulk-heterojunction (BHJ) or planar-heterojunction (PHJ). If BHJ-OPVs allow achieving highest efficiencies, PHJ-OPVs, due to their simplicity, permit obtaining more reproducible results [7]. Moreover, while when a fullerene derivative is used as electron acceptor in BHJ-OPV it is well admitted that its contribution to the OPV current is small, it appears that it is not so evident in the case of inverted PHJ-OPVs (i.e. PHJ-IOPV). As a matter of fact, in the present work, using $\mathrm{SubPc} / \mathrm{C}_{60}$ as heterojunction $\mathrm{ED} / \mathrm{EA}$ in PHJ-IOPVs, we show that, if the SubPc contribution to the external quantum efficiency (EQE), is dominant, that of $\mathrm{C}_{60}$ is far to be negligible. This experimental result is comforted by optical simulation of the OPVs. On the other hand, it is well admitted that flexible optoelectronic is promised rapid development in the coming years [8]. Therefore, ITO being poorly flexible, it is necessary to look for new flexible transparent electrodes. Among the possible substituents, Dielectric/Metal/Dielectric (DMD) structures are one of the most promising [9]. We have probed two of these DMD structures as cathodes in the inverted OPVs studied in the present work. We show that the transmission spectrum of the TCEs is primordial for OPVs performances.

\section{Description of approach and techniques}

As described in supporting S1, OPVs were realized by deposition under vacuum on TCE coated glass substrates [10]. The optically and electrically active core of the cells consisted of the planar heterojunction $\mathrm{SubPc} / \mathrm{C}_{60}$. The transparent electrode was either ITO or a DMD 
structure. Two kinds of DMD structures were used, $\mathrm{ZnS} / \mathrm{Ag} / \mathrm{TiO}_{2}$, with the thicknesses 31 $\mathrm{nm} / 10 \mathrm{~nm} / 31 \mathrm{~nm}$ for the different layers [11], and $\mathrm{MoO}_{3} / \mathrm{Ag} / \mathrm{MoO}_{3}$, with $35 \mathrm{~nm} / 11 \mathrm{~nm} / 15 \mathrm{~nm}$ respectively [12].The second electrode was an aluminum layer thick of $100 \mathrm{~nm}$. It is known that to optimize the charge collection it is necessary to introduce buffer layers at the electrode/organic material interfaces [13]. At the interface anode/SubPc we have introduced a thin $\mathrm{MoO}_{3}$ layer as hole transporting layer (HTL), $\mathrm{MoO}_{3}$ being well known as very efficient hole collector, even if the work function of the anode itself is not very high [14]. As electron transporting layer (ETL), $\mathrm{Alq}_{3}$ (Tris (8-hydroxyquinoline) aluminum), was introduced between the cathode and the fullerene. When used in COPVs, the $\mathrm{Alq}_{3}$ ETL is called exciton blocking layer (EBL) and was proved to be very efficient [15]. All chemical products were provided by Aldrich and CODEX. The different layers evocated above were sequentially deposited such as, in the classical configuration, we had Glass $/ \mathrm{TCE} / \mathrm{MoO}_{3} / \mathrm{SubPc} / \mathrm{C}_{60} / \mathrm{Alq}_{3} / \mathrm{Al}$ and in the inverted geometry Glass $/ \mathrm{Alq}_{3} / \mathrm{C}_{60} / \mathrm{SubPc} / \mathrm{MoO}_{3} / \mathrm{Al}$ (supporting information S2).

The device energy diagrams for both OPV configurations are shown in Figure 1.

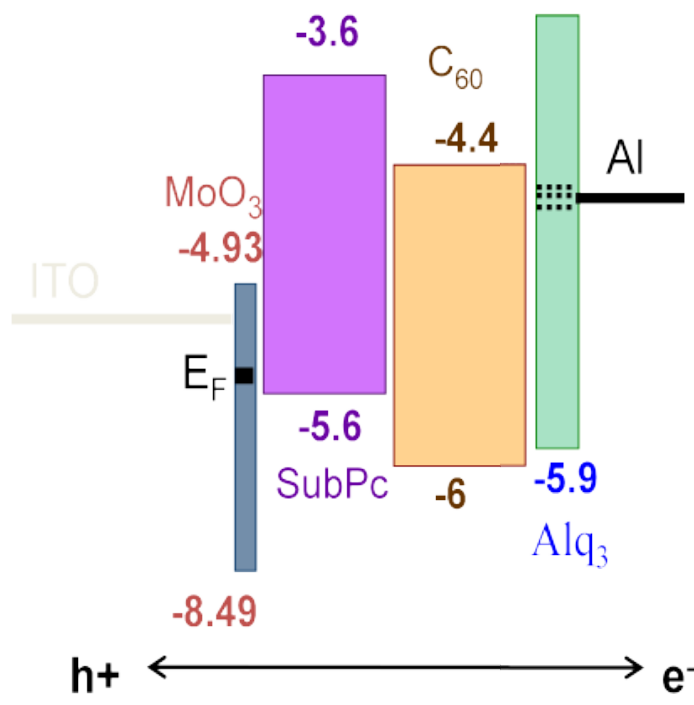

(a: COPV)

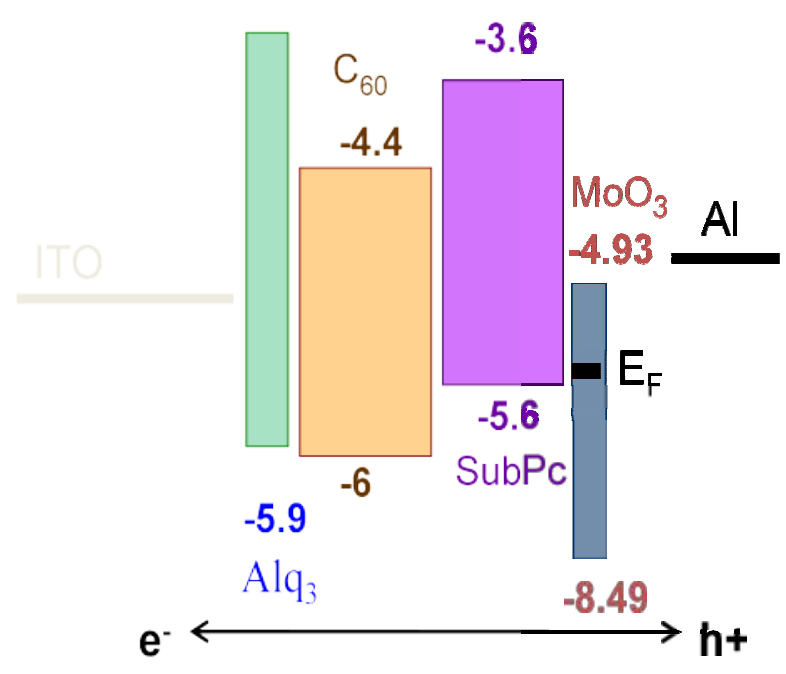

(b: IOPV)

Figure 1: Device energy diagrams for both OPV configurations: (a) COPV, (b) IOPV.

After realization, the OPVs were characterized by J-V, External Quantum Efficiency (EQE) and optical absorption measurements (these experimental techniques are presented in the supporting information S3). 


\section{Experimental results and discussion}

3.1 Optimization of the performances of the inverted OPVs, ITO being the transparent electrode.

As evocated before, the main goal of this work is to study the contribution of $\mathrm{C}_{60}$ to the photocurrent of OPVs and, more precisely, to compare its contribution in the classical OPVs to that in the inverted OPVs. To carry out this comparison, all other things being equal, we used in the inverse cells, the same materials as in the classical cells. Therefore, knowing that for classical cells the configuration was Glass/ITO/ $/ \mathrm{MoO}_{3} / \mathrm{SubPc} / \mathrm{C}_{60} / \mathrm{Alq}_{3} / \mathrm{Al}$, for reverse structures we used the configuration Glass $/ \mathrm{ITO} / \mathrm{Alq}_{3} / \mathrm{C}_{60} / \mathrm{SubPc} / \mathrm{MoO}_{3} / \mathrm{Al}$. We have already shown that, in the case of inverted OPVs it was difficult to achieve reproducible performances [16]. Actually, it was demonstrated that the open circuit voltage (Voc), the fill factor (FF) and therefore the OPV efficiency $(\eta)$ depend on the morphology of the SubPc layer, which itself depends on its deposition rate. Optimum results were obtained when the deposition rate of SubPc was $0.02 \pm 0.01 \mathrm{~nm} / \mathrm{s}$, the SubPc films being homogeneous. For higher deposition rate, the Voc and FF values and the reproducibility of the results decrease. It was also shown that the optimum thickness of the SubPc layer was $16 \mathrm{~nm}$, for smaller or higher thickness the OPV efficiency decreases [16]. At the beginning of the present work, even after optimization of the deposition rate and film thickness of SubPc, some variations in Voc and FF values persist. Actually, the SubPc purity given by our supplier was 85 at. \%, which means that from one batch to another one some significant differences can be encountered. This crucial point should be overcome. Therefore we had to purify the material. It was shown earlier that it was possible to purify phthalocyanine dyes by simply carrying out successive sublimations. Indeed, by using the same charge in the sublimation crucible, there is a progressive "auto purification" of the phthalocyanine dye [17]. Taking advantage of our experience acquired with the $\mathrm{CuPc}$ [18] we undertaken the purification of SubPc by a series of initial deposits which aimed to optimize the efficiency of the cells. Typical results are summarized in Figure 2. It can be seen that the performances of the OPVs depend very significantly of the number of deposits made, mainly through the values of Voc and FF. 


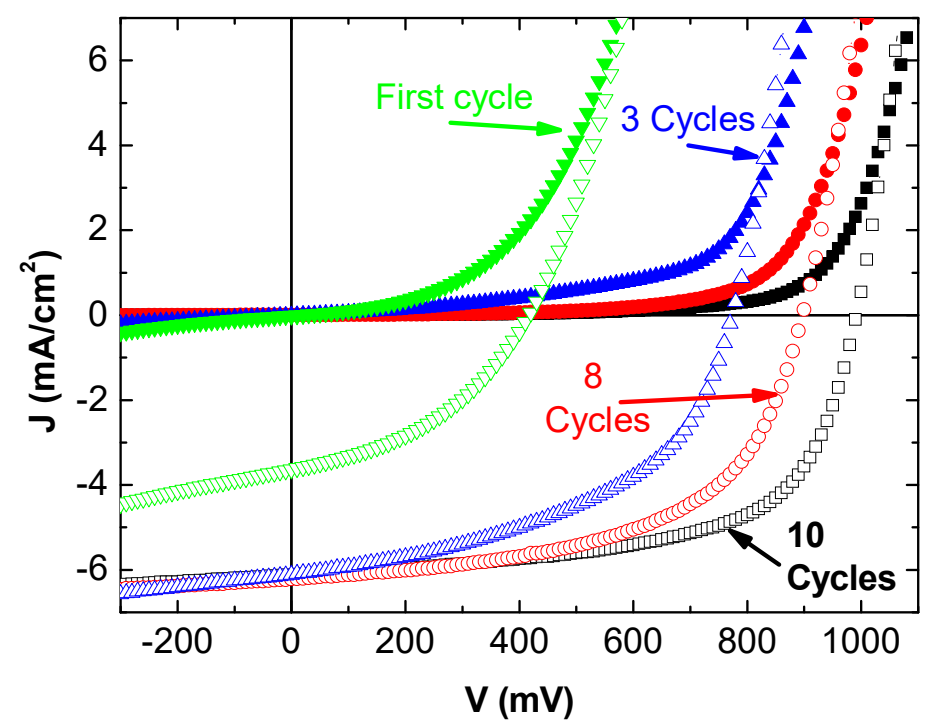

Figure 2: Optimization of the J-V characteristics of inverted OPV by purifying SubPc through deposition cycles: 1 cycle $(\boldsymbol{\nabla}), 3$ cycles $(\boldsymbol{\Delta}), 8$ cycles $(\bullet)$ and 10 cycles $(\boldsymbol{\square})$ (the filled symbols correspond to dark conditions while the open symbols correspond to light AM 1.5 conditions).

It is clear that Voc and FF increase with the number of cycles of deposits. For the first deposition, SubPc layer quality is very poor as shown by the $\mathrm{J}-\mathrm{V}$ characteristics obtained. Then, up 10 cycles, there is a progressive improvement of these characteristics due to the increase of Voc and FF while Jsc does not vary significantly after 3 cycles. From 10 cycles the characteristics are optimal and stable. It must be noted that our experience with $\mathrm{CuPc}$ discard the hypothesis of a possible artifact due to a problem on our equipment to deposit the film. Actually when the purity of $\mathrm{CuPc}$ is $99 \%$, it is not necessary to carry out successive sublimations to obtain stable results, while it is necessary when the purity of CuPc is only $95 \%$ [18]. The effectiveness of our process in purifying these phthalocyanine dyes shows that some impurities present in the commercial powder have smaller sublimation temperature than the dyes, which allows the purification through deposition cycles.

After stabilization of the OPCs performances, i.e. purification of the SubPc present in the sublimation crucible, we proceeded to the comparison of the J-V characteristics and the EQE spectra of inverted and classical OPVs.

3.2 Classical and inverted OPVs using ITO as transparent electrode 
The J-V characteristics of the inverted and classical OPVs manufactured during the present work are represented in figure 3. The champion IOPV produced a Jsc of $6.12 \mathrm{~mA} / \mathrm{cm}^{2}$, a Voc of $0.99 \mathrm{~V}$, a FF of 0.61 and $\eta$ of $3.76 \%$, while Rs $=20 \Omega$ and Rsh $=1800 \Omega$. On the other hand, the COPV produced a Jsc of $7.65 \mathrm{~mA} / \mathrm{cm}^{2}$, a Voc of $1.00 \mathrm{~V}$, a FF of 0.58 and $\eta$ of $4.44 \%$, while $\mathrm{Rs}=15 \Omega$ and $\mathrm{Rsh}=1300 \Omega$. The obtained results are rather close, the main difference being due to Jsc, which is smaller in the case of IOPV, as it is often the case in PHJ-OPVs.

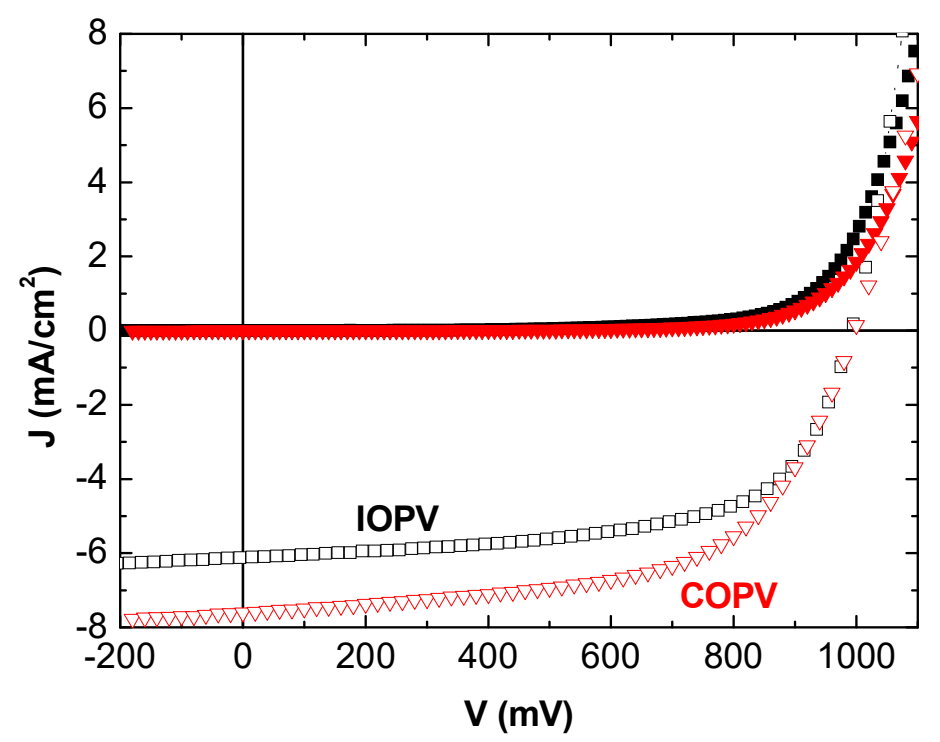

Figure 3: J-V characteristics of IOPV ( $\mathbf{\square})$ and COPV ( $\boldsymbol{\nabla})$ (the filled symbols correspond to dark conditions while the open symbols correspond to light AM 1.5 conditions).

Typical EQE spectra of both types of OPVs are presented in Figure 4 and absorption spectra are shown in Figure 5. In the EQE spectra the signal situated between $500 \mathrm{~nm}$ and $650 \mathrm{~nm}$ can be attributed to SubPc. In the short wavelengths spectral range, the signal below $400 \mathrm{~nm}$ corresponds to the second absorption band of SubPc, but above all to $\mathrm{C}_{60}$. As shown by the absorption curves, the intermediate domain between these two contributions must be mainly attributed to $\mathrm{C}_{60}$. It is remarkable to note that the $\mathrm{C}_{60}$ contribution in EQE is far to be negligible in the case of IOPV. In order to check the importance of the contribution of $\mathrm{C}_{60}$ to the short circuit current we have studied series of IOPVs with different thicknesses of $\mathrm{C}_{60}: 20$ $\mathrm{nm}, 30 \mathrm{~nm}$ and $40 \mathrm{~nm}$. Typical J-V characteristics are reported in the supporting information S4. The main information, which confirms the importance of the contribution of $\mathrm{C}_{60}$, is that the value of Jsc decreases when the thickness of $\mathrm{C}_{60}$ decreases: $\mathrm{Jsc}_{\mathrm{sc}}=4.10 \mathrm{~mA} / \mathrm{cm}^{2}$ when the 
thickness of $\mathrm{C}_{60}$ is $20 \mathrm{~nm}, \mathrm{Jsc}=4.95 \mathrm{~mA} / \mathrm{cm}^{2}$ for $30 \mathrm{~nm}$ and $\mathrm{Jsc}=6.12 \mathrm{~mA} / \mathrm{cm}^{2}$ for $40 \mathrm{~nm}$ of $\mathrm{C}_{60}$. Beyond, Jsc starts to decrease due to the increase of the series resistance.

It can be seen in Figure 5 that the overall shape of the absorption spectra of IOPV and COPV are rather similar. Nevertheless, the ratio of the values measured at $450 \mathrm{~nm}$ and $590 \mathrm{~nm}$ $\left(\mathrm{OD}_{450} / \mathrm{OD}_{590} \mathrm{~nm}\right)$ is different. It is greater than 1 in the case of IOPVs and smaller than 1 for COPVs, i.e. the contribution of $\mathrm{C}_{60}$ is dominant in IOPVs. Moreover, it can be noted that the $\mathrm{C}_{60}$ contribution in the UV spectral domain is very important.

Since the EQE spectra are clearly dependent of the absorption spectra of the organic layers, as shown by the Figures 3 and 4, we have proceeded to a simulation of the optical absorption of the different structures in order to try to discriminate the contribution of each constituent to the OPVs current.

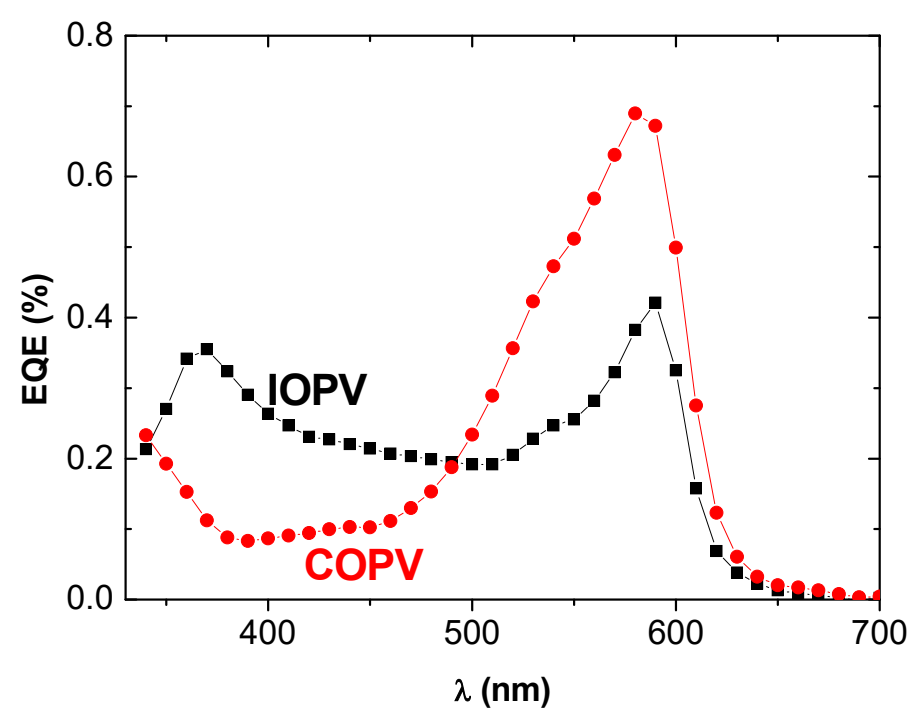

Figure 4: Typical EQE spectra of IOPV (घ) and COPV (•). 


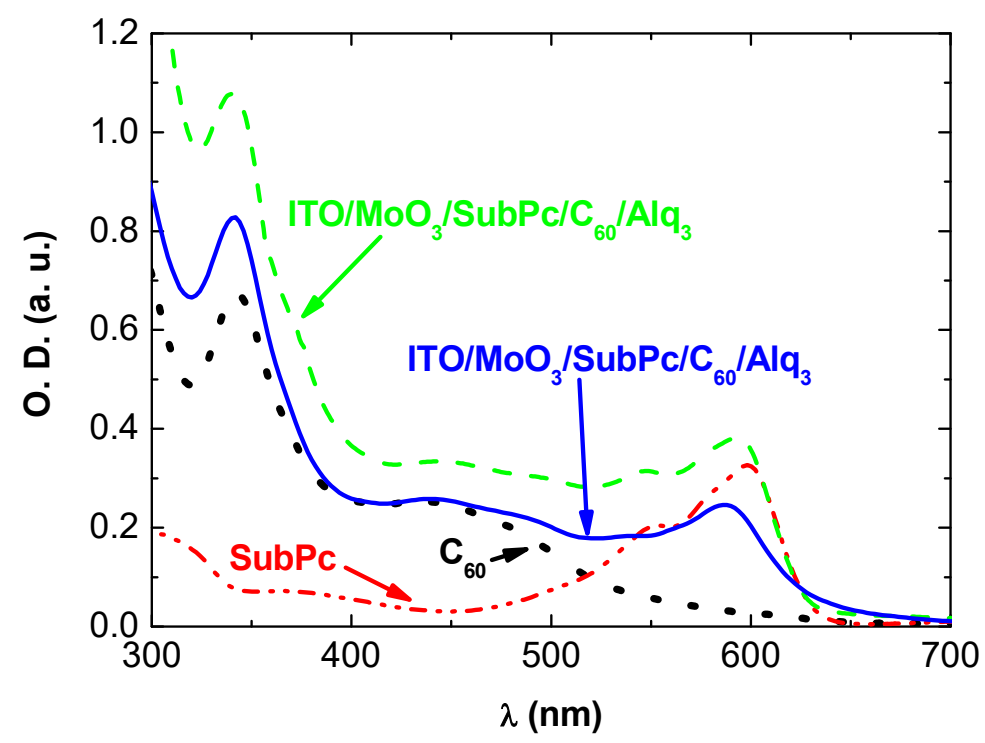

Figure 5: Optical absorption spectra of $\operatorname{SubPc}(\bullet-\bullet-\bullet), \mathrm{C}_{60}(\bullet \bullet \bullet \bullet)$, $\mathrm{ITO} / \mathrm{Alq}_{3} / \mathrm{C}_{60} / \mathrm{SubPc} / \mathrm{MoO}_{3}(\neg-\backsim)$ and ITO $/ \mathrm{MoO}_{3} / \mathrm{SubPc} / \mathrm{C}_{60} / \mathrm{Alq}_{3}(\longrightarrow)$.

\subsection{Optical simulation}

A numerical model based on a Transfer Matrix Method (TMM), is employed to predict the optical behavior of the considered electrodes or organic solar cells $[19,20]$. It supposes that the stacks are composed of flat, massive and homogeneous layers, that the air surrounds the multilayer, and that light penetrates at normal incidence. The input data of our simulation algorithm are the thicknesses of each material and their complex optical constants, previously obtained by ellipsometric spectroscopy or by scientific literature [21, 22]. The parameters used for the simulation of transmission spectrum are given in the supporting information S5 and in the references [21, 23].

This method makes it possible to calculate the optical properties such as the reflectance $\mathrm{R}$, the transmittance $\mathrm{T}$ and the absorbance $\mathrm{A}$, and to optimize the thicknesses of our structures [22, 23]. As an example, we are able to compare the modeled transmittance to those measured (figure 6) from a typical $\mathrm{ZnS} / \mathrm{Ag} / \mathrm{TiO}_{\mathrm{x}}$ electrode manufactured by a vacuum electron beam evaporator on a glass substrate, then characterized by UV-Visible spectrophotometer. Results are globally in good agreement for such Glass/ZnS $(31 \mathrm{~nm}) / \operatorname{Ag}(10 \mathrm{~nm}) / \mathrm{TiOx}(31 \mathrm{~nm})$ electrode (the measured curve is in full line while the simulated curve is in dashed line). 


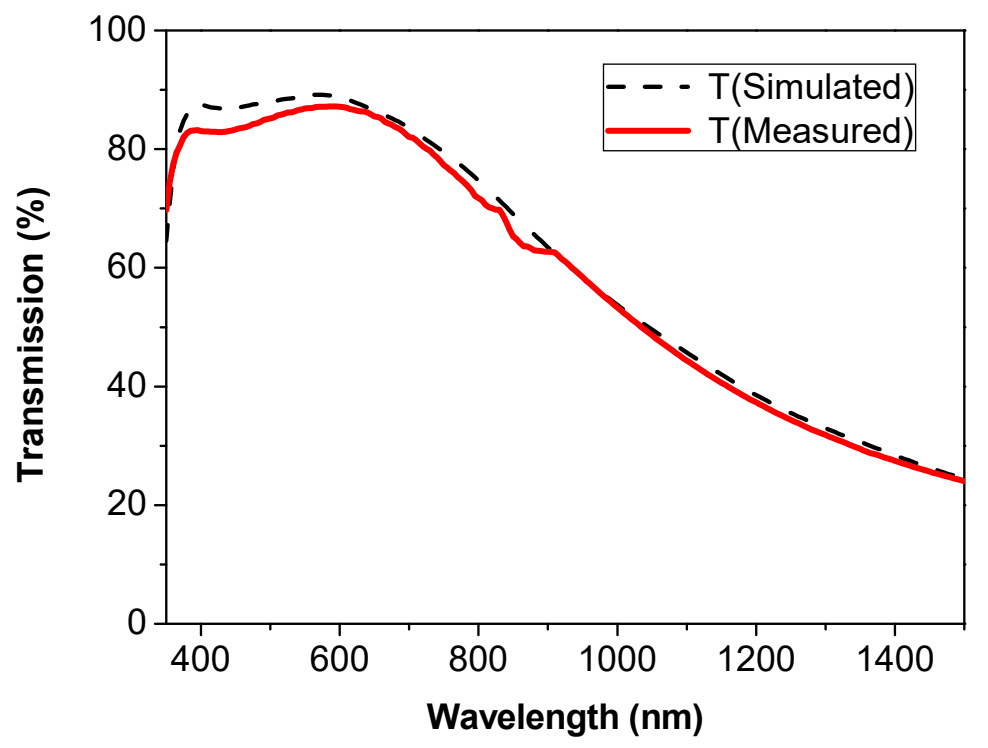

Figure 6: Simulated (dashed line) and measured (full line) Transmittance (T), for Glass/ZnS(31 nm)/Ag(10 nm)/TiOx(31 nm) electrode.

Our optical numerical method was used to calculate the total absorbance in a classical design (COPV): ITO (80) / $\mathrm{MoO}_{3}$ (4) / SubPc (20) / $\mathrm{C}_{60}$ (45) / $\mathrm{Alq}_{3}(9) / \mathrm{Al}$, and in an inverted design (IOPV): ITO (80) / $\mathrm{Alq}_{3}(9) / \mathrm{C}_{60}(45) / \mathrm{SubPc}(16) / \mathrm{MoO}_{3}(4) / \mathrm{Al}$ (the values in brackets are the thicknesses of each layer in $\mathrm{nm}$ ). We observe in figure 7 the absorbance of such solar cells in the [400, 1200]-nm spectral range, and note a significant difference of optical behavior between COPV and IOPV in the [400, 700]-nm range. 


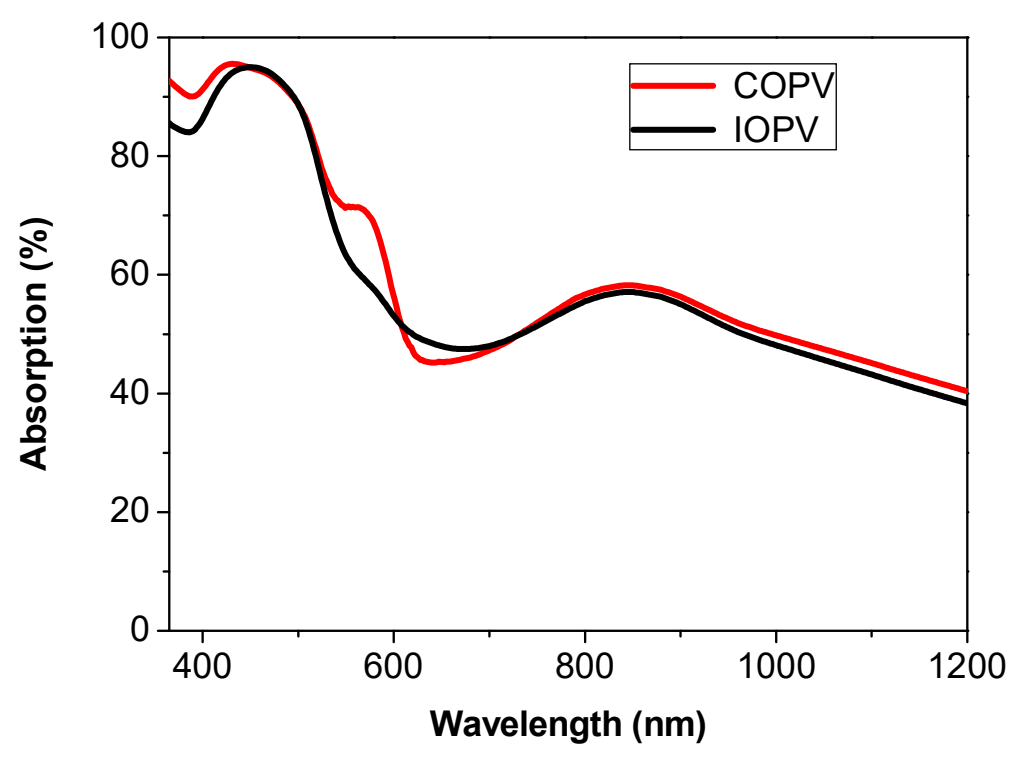

Figure 7: Total absorption in the following OPV cells:

- COPV classical design: ITO (80)/ $\mathrm{MoO}_{3}(4) / \mathrm{SubPc}(20) / \mathrm{C}_{60}(45) / \mathrm{Alq}_{3}(9) / \mathrm{Al}$

- IOPV inverted design: ITO (80) / $\mathrm{Alq}_{3}(9) / \mathrm{C}_{60}(45) / \mathrm{SubPc}(16) / \mathrm{MoO}_{3}(4) / \mathrm{Al}$

However, only the absorbance in the photo-active layers is likely to produce photocurrent in the cells. Therefore, we calculated the useful intrinsic absorption in the only SubPc and $\mathrm{C}_{60}$ active layers in order to correlate our results with the EQE ones in the same spectral domain (figure 8). It appears clearly in the classical design two absorption bands: one below the wavelength of $550 \mathrm{~nm}$ which is mainly due to the absorption of the $\mathrm{C}_{60}$ acceptor material, and one above this wavelength that is mainly attributed to the SubPc donor molecule. In the inverted cell, the optical contribution of the $\mathrm{C}_{60}$ is increased between 425 and $525 \mathrm{~nm}$, while those of the SubPc is decreased between 525 and $600 \mathrm{~nm}$. These variations can be explained by the optical interferences taking place in the whole stack, which modify the distribution of the electromagnetic field and thus the absorbance, and by the thickness of the SubPc that is a little smaller in the inverted cell. 


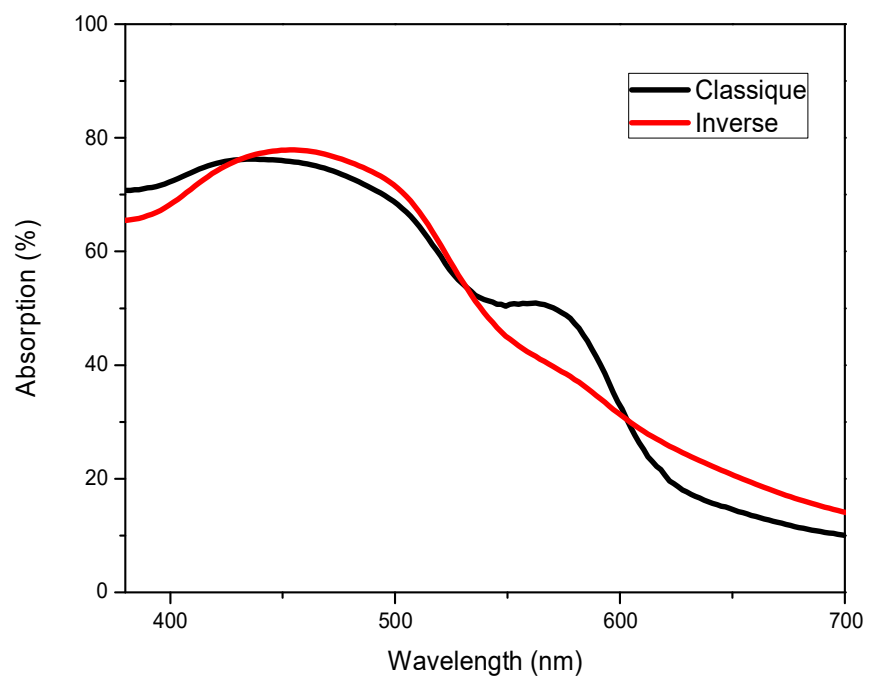

Figure 8: Absorption of the only $\left(\mathrm{SubPc}+\mathrm{C}_{60}\right)$ active materials inside inverted (IOPV) and classical (COPV) design.

It is also remarkable to note some strong similarities with the EQE curves of the figure 4 as the presence of a "crossing" wavelength (around 500-525 nm) between 2 spectral domains where the COPV is better than IOPV (in the [500-520, 600]-nm range), and where the IOPV is better than COPV (in the [350-400, 500-520]-nm range). This demonstrates the significant influence of the absorption on the EQE of the OPVs, and the non-negligible contribution of the $\mathrm{C}_{60}$ acceptor molecule in its absorption range.

\subsection{Inverted OPVs with different transparent conductive electrodes}

After the study of OPVs using ITO as TCE, we have substituted DMD to ITO, using two different types of DMD: $\mathrm{ZnS} / \mathrm{Ag} / \mathrm{TiO}_{2}$ and $\mathrm{MoO}_{3} / \mathrm{Ag} / \mathrm{MoO}_{3}$. We have used them as cathode, the main goal of the present study being not to match the performances obtained with ITO, but to study the influence of the transmission curves of the new TCEs on the electrical characteristics of IOPVs. The transmission curves of the different TCEs used are visible in Figure 9. It can be seen that there is a decrease of the light transmission of the $\mathrm{ZnS} / \mathrm{Ag} / \mathrm{TiO}_{2}$ structure for wavelengths below $375 \mathrm{~nm}$, while in the spectral range above $550 \mathrm{~nm}$, the MAM structure is the TCE that transmits the least. In Figure 9 we have also introduced the absorption spectra of SubPc and $\mathrm{C}_{60}$ in order to facilitate the discussion of the shape of the EQE curves further shown. If the main contribution of the absorption spectrum of SubPc is situated in the wavelength range that corresponds more or less to the maximum transmission range of the three TCEs, it is not the case with $\mathrm{C}_{60}$. Actually, the main contribution of the 
absorption spectrum of $\mathrm{C}_{60}$ is situated in the very short wavelengths range (below $400 \mathrm{~nm}$ ), with the second absorption peak of SubPc.

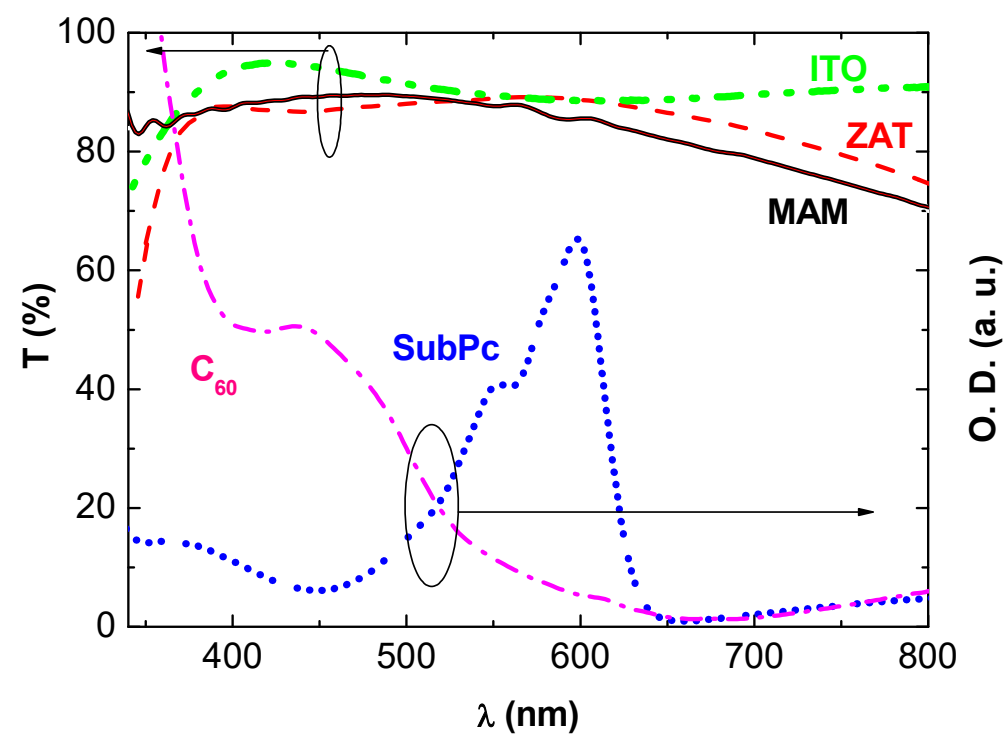

Figure 9: Typical transmission spectra of $\mathrm{MoO}_{3} / \mathrm{Ag} / \mathrm{MoO}_{3}(-), \mathrm{ZnS} / \mathrm{Ag} / \mathrm{TiO}_{2}(\neg-\backsim)$ and ITO $(\bullet \bullet-)$ and absorption spectra of $\mathrm{C}_{60}(\bullet \bullet-)$ and $\operatorname{SubPc}(\bullet \bullet)$.

Typical J-V characteristics obtained with the new TCEs, when they are substituted to ITO in IOPVs, are shown in Figure 10 and summarized in Table 1, while the corresponding EQE spectra are shown in Figure 11. The performances are sensibly smaller than that achieved with the ITO electrode. Actually, in the case of $\mathrm{ZnS} / \mathrm{Ag} / \mathrm{TiO}_{2}-\mathrm{TCE}$, we have already shown that the performances of the OPVs, are limited by the diffusion of some Ag towards the surface of the TCE [24]. In the case of $\mathrm{MoO}_{3} / \mathrm{Ag} / \mathrm{MoO}_{3}$ it can be seen that with the ETL used in the present work, $\mathrm{Alq}_{3}$, the result is very bad. As a matter of fact, it is known that the value of the work function $\left(\mathrm{W}_{\mathrm{F}}\right)$ of $\mathrm{MoO}_{3}$ is higher than $5 \mathrm{eV}$, which makes that it is a very efficient HTL [25] but reversely a very bad ETL. 


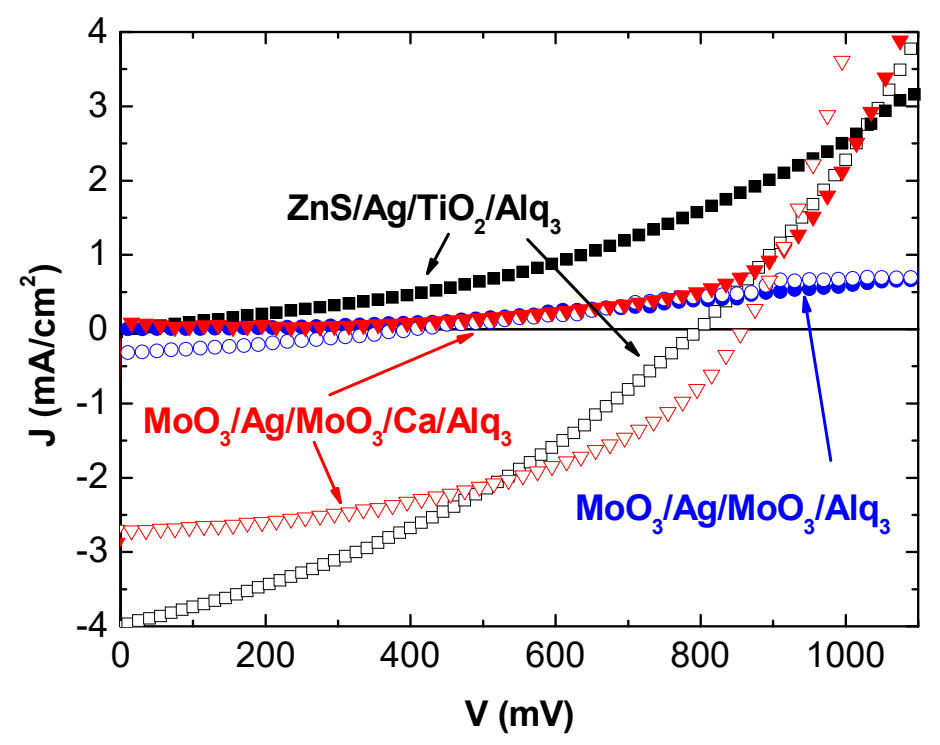

Figure 10: J-V characteristics of IOPV with $\mathrm{ZnS} / \mathrm{Ag} / \mathrm{TiO}_{2} / \mathrm{Alq}_{3}(\boldsymbol{\bullet}), \mathrm{MoO}_{3} / \mathrm{Ag} / \mathrm{MoO}_{3} / \mathrm{Alq}_{3}(\bullet)$ and $\mathrm{MoO}_{3} / \mathrm{Ag} / \mathrm{MoO}_{3} / \mathrm{Ca} / \mathrm{Alq}_{3}(\boldsymbol{\nabla})$ as cathode/ETL (the filled symbols correspond to dark conditions while the open symbols correspond to light AM 1.5 conditions).

So, when used as cathode in IOPVs the efficiency of the cells is very small. Nevertheless, when a small $\mathrm{W}_{\mathrm{F}}$ material, $\mathrm{Ca}$, is introduced at the interface cathode/organic material, a far better result is obtained. Knowing that the goal of the present study was not to overpass some record but to study the effect of the transmission spectra of the new TCE on the IOPVs performances we focused our attention on the EQE spectra. It can be seen in Figure 11, that the contribution of the main SubPc absorption peak is clearly visible for all samples.

However, in the small wavelengths range, the EQE signal decreases when $\mathrm{ZnS} / \mathrm{Ag} / \mathrm{TiO}_{2}$ is the cathode, while a contribution to the current is clearly visible with other TCEs.

\begin{tabular}{cccccc}
\hline Cathode & ETL & Voc (V) & $\begin{array}{c}\text { Jsc } \\
(\mathrm{mA} / \mathrm{cm} 2)\end{array}$ & FF (\%) & $\eta(\%)$ \\
\hline $\mathrm{ZnS} / \mathrm{Ag} / \mathrm{TiO}_{2}$ & $\mathrm{Alq}_{3}$ & 0.80 & 4.00 & 36 & 1.15 \\
$\mathrm{MoO}_{3} / \mathrm{Ag} / \mathrm{MoO}_{3}$ & $\mathrm{Alq}_{3}$ & 0.40 & 0.32 & 31 & 0.04 \\
$\mathrm{MoO}_{3} / \mathrm{Ag} / \mathrm{MoO}_{3}$ & $\mathrm{Ca} / \mathrm{Alq}_{3}$ & 0.86 & 2.71 & 48 & 1.10 \\
\hline
\end{tabular}

Table 1: Typical parameters of IOPVs (Cathode/ETL/ $\left.\mathrm{C}_{60} / \mathrm{SubPc} / \mathrm{MoO}_{3} / \mathrm{Al}\right)$ with different cathodes. 
More precisely, relatively to the maximum of the SubPc contribution, the $\mathrm{MoO}_{3} / \mathrm{Ag} / \mathrm{MoO}_{3}-$ TCE permits the best answer. These results can be discussed in the light of the spectra of transmission of TCEs and absorption of SubPc and $\mathrm{C}_{60}$. We have seen (Figure 9) that there is a decrease of the light transmission of the $\mathrm{ZnS} / \mathrm{Ag} / \mathrm{TiO}_{2}-\mathrm{TCEs}$ just in the range where the $\mathrm{C}_{60}$ absorption is maximum, while that of $\mathrm{MoO}_{3} / \mathrm{Ag} / \mathrm{MoO}_{3}$ is higher than that of ITO, which justifies the shape of the EQE spectra.

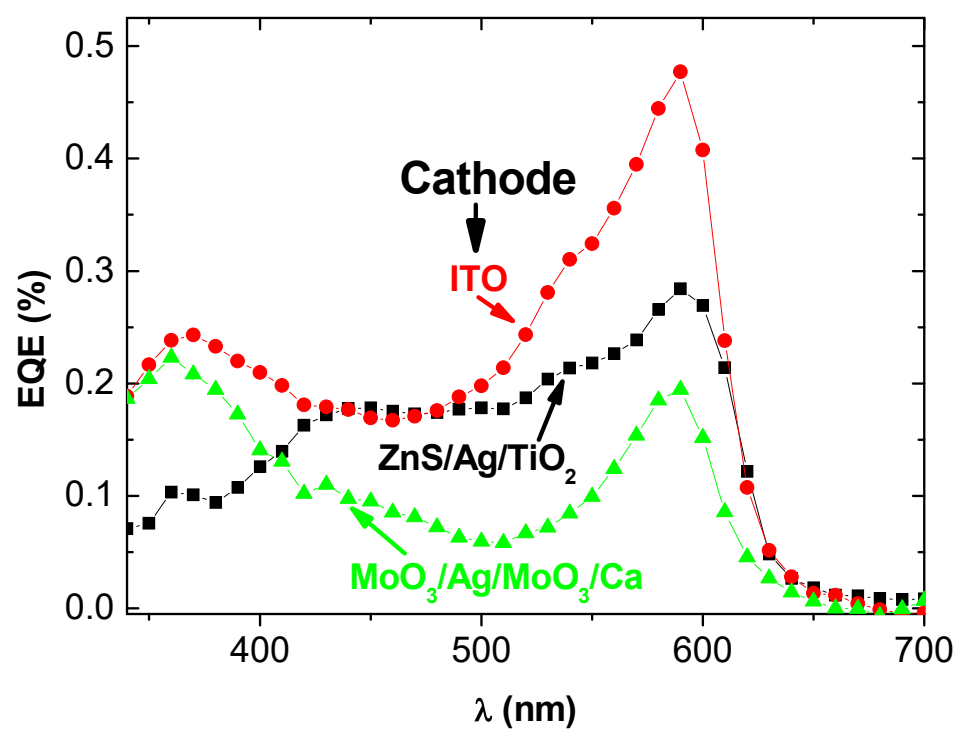

Figure 11: Typical EQE spectra of IOPV with different cathodes: $(\boldsymbol{\varpi}) \mathrm{ZnS} / \mathrm{Ag} / \mathrm{TiO}_{2},(\bullet)$ ITO and $(\Delta) \mathrm{MoO}_{3} / \mathrm{Ag} / \mathrm{MoO}_{3}$.

\section{Conclusion}

In the present work we demonstrate that, in the case of PHJ-IOPVs, the contribution of the $\mathrm{C}_{60}$ layer to the $\mathrm{Jsc}$, if not principal, is far to be negligible. As a matter of fact, the contribution of SubPc to Jsc is dominant in the visible range, while that of $\mathrm{C}_{60}$ prevails in the short wavelengths spectral range. These results are corroborated by the optical simulation, which demonstrates the non-negligible contribution of the $\mathrm{C}_{60}$ acceptor molecule to the absorption of inverse OPVs in the UV-part of the spectral range and therefore to Jsc. Moreover, we show that the transmission spectrum of the TCE is determinant for the shape of the EQE spectrum and thus for Jsc and the OPV efficiency. The alternative $\mathrm{ZnS} / \mathrm{Ag} / \mathrm{TiO}_{2}$ indium-free TCE is also proved to be a credible alternative to ITO. However, if $\mathrm{TiO}_{2}$ is a good electron collector, 
due to its weak extraction work, the decrease in its transmission below the wavelength of 400 nm penalizes the PHJ-OPVs performances.

\section{Acknowledgements}

The authors acknowledge funding from the European Community ERANETMED_ENERG11-196: Project NInFFE "New Indium Free Flexible Electrode".

\section{References}

1- Christopher J. M. Emmott, Jason A. Röhr, Mariano Campoy-Quiles, Thomas Kirchartz, Antonio Urbina, Nicholas J. Ekins-Daukes and Jenny Nelson, 2019 Organic photovoltaic greenhouses: a unique application for semi-transparent PV?, Energy Environ. Sci. DOI: 10.1039/c4ee03132f

2- Chang Liu, Kai Wang, Xiong Gong and Alan J. Heeger, 2015 Low bandgap semiconducting polymers for polymeric photovoltaics, Chem. Soc. Rev DOI: $10.1039 / \mathrm{c} 5 \operatorname{cs} 00650 \mathrm{c}$

3- Guangye Zhang, Jingbo Zhao, Philip C. Y. Chow, Kui Jiang, Jianquan Zhang, Zonglong Zhu, Jie Zhang, Fei Huang, and He Yan, 2018 Non fullerene Acceptor Molecules for Bulk Heterojunction Organic Solar Cells, Chem. Rev. 118 3447-3507

4- Tayebeh Ameri, Gilles Dennler, Christoph Lungenschmied and Christoph J. Brabec, 2009 Organic tandem solar cells: A review, The Royal Society of Chemistry DOI: 10.1039/b817952b.

5- L. Cattin, C. Cabanetos, A. El Mahlali, L. Arzel, M. Morsli, P. Blanchard, J.C. Bernède, 2020 Smart geometrical approach to intercalate a highly absorbing and quite resistive electron donor layer in ternary organic photovoltaic cells, Organic Electronics 76105463.

6- Fujun Zhang, XiaoweiXu, Weihua Tang, Jian Zhang, Zuliang Zhuo, Jian Wang, Jin Wang, Zheng $\mathrm{Xu}$, Yongsheng Wanga, 2011 Recent development of the inverted configuration organic solar cells Solar Energy Materials \& Solar Cells 95 1785-1799

7- J. C. Bernède, “Organic photovoltaic cells: History, principle and techniques, 2008 Journal of The Chilean Chemical Society 53 1549-1564.

8- Yaowen Li, Guiying Xu, Chaohua Cui, Yongfang Li, 2018 Flexible and Semitransparent Organic Solar Cells, Adv. Energy Mater. 8 1701791, doi.org/10.1002/aenm.201701791 
9- L. Cattin, J.C. Bernède, M. Morsli, 2013Toward indium-free optoelectronic devices: Dielectric / Metal / Dielectric alternative conductive transparent electrode in organic photovoltaic cells. Physica Status Solidi a 210 1047-1061

10- L. Cattin, J.C. Bernède, Y. Lare, S. Dabos- Seignon, N. Stephant, M. Morsli, P.P.Zamora, F.R. Diaz, M.A. del Valle, 2013 Improved performance of organic solar cells by growth optimization of $\mathrm{CuI} / \mathrm{MoO}_{3}$ double anode buffer, Physica Status Solidi a 210 802-808

11- M. A. Cherif, A. Labiod, D. Barakel, S. Touihri, and Ph. Torchio, 2019 "Tailored $\mathrm{ZnS} / \mathrm{Ag} / \mathrm{TiOx}$ Transparent and Conductive Electrode for Organic Solar Cells", EPJ Photovoltaics, Vol. 10, No. 2

12- J. C. Bernède, L. Cattin, 2019 Dielectric/Metal/Dielectric flexible transparent electrodes, from smart window to semi-transparent solar cells, Asian Journal of Engineering and Technology, 7 176-195; Asian Online Journals (www.ajouronline.com).

13- A. Godoy, L. Cattin, L. Toumi, F.R. Diaz, M.A. del Valle, G.M. Soto, B. Kouskoussa, M. Morsli, K. Benchouk, A. Khelil, J.C. Bernède, 2010 Effects of the buffer layer inserted between the transparent conductive oxide anode and the organic electron donor, Solar Energy Materials \& Solar Cells 94 648-654

14- Sun F-Z, Shi A-L, Xu Z-Q, Wei H-X, Li Y-Q, Lee S-T, et al. 2013 Efficient inverted polymer solar cells with thermal-evaporated and solution-processed small molecular electron extraction layer. Appl Phys Lett;102:133303.

15- Q.L. Song, F.Y. Li, H. Yang, H.R. Wu, X.Z. Wang, W. Zhou, J.M. Zhao, X.M. Ding, C.H. Huang, X.Y. Hou, 2005 Small-molecule organic solar cells with improved stability, Chem. Phys. Lett. 416 42-46

16- A. Mohammed-Krarroubik, M. Morsli, A. Khelil, L. Cattin, L. Barkat, S. Tuo, Z. El Jouad, G. Louarn, M. Ghamnia, M. Addou, and J. C. Bernède, 2017 The Influence of Deposition Rates on Properties of $\mathrm{AlPcCl}$ Thin Films and on the Performance of Planar Organic Solar Cells, Phys. Status Solidi A, 1700367, DOI: 10.1002/pssa.201700367.

17- RF. Salzman, J. Xue, B.P. Rand, A. Alexander, M.E. Thompson, S.R Forrest, 2005 Organic Electron. 6242

18- Y. Berredjem, N. Karst, A. Boulmokh, A. Drici, and J.C. Bernède, 2007 Optimisation of the interface "organic material/aluminium"of CuPc/C60 based photovoltaic cells, Eur. Phys. J Appl. Phys. 40 163-167, DOl 10.1051/epjap: 2007145. 
19- A. Bou, Ph. Torchio, D. Barakel, F. Thierry, A. Sangar, P.Y. Thoulon, and M. Ricci, 2014 Indium Tin Oxyde-free Transparent and Conductive Electrode based on $\mathrm{SnOx}|\mathrm{Ag}| \mathrm{SnOx}$ for Organic Solar Cells, Journal of Applied Physics, Vol. 116, No. 2, 023105.

20- L. Peres, A. Bou, D. Barakel, and Ph. Torchio, 2016 ZnS/Ag/TiO 2 Multilayer Electrodes with Broadband Transparency for Thin Film Solar Cells, RSC Advances, Vol. 6, pp. 6105761063.

21- E. Palik, 1997 Handbook of Optical Constants of Solids, Elsevier I.

22 24- Y. Mouchaal, G. Louarn, A. Khelil, M. Morsli, N. Stephant, A. Bou, T. Abachi, L. Cattin, M. Makha, Ph. Torchio, and J.C. Bernède, 2015 Broadening of the Transmission Range of Dielectric/Metal Multilayer Structures by using Different Metals, Vacuum, 111, pp. $32-41$.

23- A. Bou, Ph. Torchio, D. Barakel, P.Y. Thoulon, and M. Ricci, 2016 Numerical and Experimental Investigation of Transparent and Conductive $\mathrm{TiOx} / \mathrm{Ag} / \mathrm{TiOx}$ Electrode, Thin Solid Films, Vol. 617 86-94

24-L. Cattin, A. El Mahlali, M. A. Cherif, S. Touihri, Z. El Jouad,Y. Mouchaal, P. Blanchard, G. Louarn, H. Essaidi, M. Addou, A. Khelil, P. Torchioand JC Bernède, 2020 New Dielectric/Metal/Dielectric electrodes for organic photovoltaic cells using either Ag or $\mathrm{Cu}: \mathrm{Ag}$ alloy as metal, J. Alloys and Compounds to be published.

25- L. Cattin, F. Dahou, Y. Lare, M. Morsli, R. Tricot, S. Houari, A. Mokrani, K. Jondo, A. Khelil, K. Napo, J.C. Bernède, $2009 \mathrm{MoO}_{3}$ surface passivation of the transparent anode in organic solar cells using ultra-thin films, Journal of Applied Physics 105034507. 